\title{
Leaving Religion in Antiquity
}

\author{
Jörgen Magnusson
}

\section{Introduction}

"A time there was when disorder ruled human lives, which were then, like lives of beasts, enslaved to force; nor was there then reward for the good, nor for the wicked punishment. Next, it seems to me, humans established laws for punishment, that justice might rule over the tribe of mortals, and wanton injury be subdued; and whosoever did wrong was penalized. Next, as the laws held [mortals] back from deeds of open violence, but still such deeds were done in secret — then, I think, some shrewd man first, a man in judgment wise, found for mortals the fear of gods, thereby to frighten the wicked should they even act or speak or scheme in secret. Hence, it was that he introduced the divine telling how the divinity enjoys endless life, hears and sees, and takes thought and attends to things, and his nature is divine so that everything which mortals say is heard and everything done is visible. Even if you plan in silence some evil deed, it will not be hidden from the gods: for discernment lies in them. So, speaking words like these, the sweetest teaching did he introduce, concealing truth under untrue speech. The place he spoke of as the gods' abode was that by which he might awe humans most - the place from which, he knew, terrors came to mortals and things advantageous in their wearisome life-the revolving heaven above, in which dwell the lightnings, and awesome claps of thunder, and the starry face of heaven, beautiful and intricate by that wise craftsman time - from which, too, the meteor's glowing mass speeds and wet thunderstorm pours forth upon the earth. Such were the fears with which he surrounded mortals, and to the divinity he gave a fitting home, by this his speech, and in a fitting place, and [thus] extinguished lawlessness by laws" (Sextus Empiricus. Against the Professors 9.54. ${ }^{1}$

We have set out to explore the leaving religion in Classical Greece by quoting the so-called Sisyphus or Critias fragment. According to this text, Gods were

1 With minor revisions, I have used the translation from Greek to English by J. Garrett which, in turn, is a revision of R.G. Bury's translation). 
invented by an intelligent person in order to stop criminal deeds. It is a telling fact that the quotation is from Sextus Empiricus who lived in the third century $\mathrm{CE}$, and the fragment has thus often been attributed to Critias, the uncle of Plato, at least six centuries earlier than the Sextus report. Other sources, however, claim that Euripides was the author of the text, but I side with Sedley who interprets the split in evidence as an indication of the authorship being simply unknown and a matter of conjecture (Sedley 2013: 142). Nevertheless, the fragment is an example of a way of speculating the emergence of religion that dates back to the second half of the fifth century вСЕ. In this chapter, we will frequently come across source critical problems that resemble those above that have been briefly touched upon. Usually, the reports of the people who have criticised the public cult or even given up religiosity all together are uncertain and from many centuries later than the occurrences described in them. However, in comparison to the sources outside the Greek speaking world, the situation is favorable although challenging indeed. Thus, with so many gaps in the information, our interpretations depend on our expectations regarding ancient religiosity in general and in many cases, in particular, on how we relate to the discourse of classical Athens as the imagined cradle of the enlightenment. Moreover, if we dare say something about the vast majority of people who did not belong to the Greek speaking élite of males, which could actually express their views on religion, even when their views were critical to the public cult, we better get to grips with how religions often function and, from that base, build up as well-founded hypotheses as possible. This prelude is my apology to why I will devote some of the very limited scope of the present chapter to topics that might be a bit surprising to be found when discussing the leaving religion in Classical Greece. To me, however, such discussions seem valuable had they been included in many of the specialised studies I have dealt with in the preparation of this chapter. The scope only allows us to discuss one of the intellectuals who might have discarded religion, and I have chosen Euripides as our example. However, I will touch upon matters that make it easier for the reader to consider whether discarding the religion was extremely rare or whether there were a larger number of people than the previously assumed who were atheists but did not dare to raise their voices.

If we discuss religions more generally, rather than focusing on theologians of creedal religions, it is increasingly recognized that there is a huge gap between the "official" beliefs that one should uphold as a believer and the different 
opinions and practices that people actually express and perform (Sorensen 2005). Harrison (2015: 24-27) suggests that one should follow trends in cognitive sciences according to which, a distinction between intuitive beliefs and reflective beliefs is made (Sperber 1996, 1997). Intuitive beliefs are beliefs that one holds without having to reflect upon them. Reflective beliefs are beliefs that you are taught or have derived by conscious reasoning (Harrison 2015:25); for instance, divine retribution is an idea one might reach at when seeing a person suffering a misfortune very well matched to the crime they are guilty of (Harrison 2000, Chapter 3). Reflective belief might then be something one reaches by inference on the basis of one or many intuitive beliefs. Such intuitive beliefs may be transmitted to somebody by the meaning of rituals or stories. It is not that uncommon that the beliefs one has reached by inference may contradict each other, as they are actualised in different contexts and may have different functions (Harrison 2015: 26-27). Even if the above discussion to a large extent has been focused on the propositional side of religious belief, the emotional aspects should not be neglected. Too often, I assert, ancient religions have been under-intellectualised whereas, for instance, Christianity has been over-intellectualised. In order to know what we in the following discussion will mean by "leaving religion," we have to determine how the category religion would relate to mystery cults and magic.

According to the paradigm that until recently has dominated the study of ancient Greek religion, the communal rituals that took place in the city constituted religion for the ancient Greeks (Kindt 2012: 1-35). Although this view has brought many valuable insights of socio-economical character, it has concealed many other important aspects of religiosity that have adhered to the private sphere and locations other than the ancient Greek city (polis). Investigations as that of Kindt (2012) have put the polis-centred paradigm into question. Moreover, a part of the critique consists of analyses showing that magic and religion were far more intertwined than what has been earlier recognized (Kindt 2012: 90-122). I am inclined to go one step further and propose that one rather than continuing to use the categories of religion, mystery cults and, magic should expand the category of religion in order to include the other two categories in it. On this basis, I will use the term religion in a more inclusive way than normally.

It is clear that the ancient Greeks did not use a term equivalent to religion (Needham 1972). However, our lack of an emic equivalent to religion does not make it useless to apply an etic term for analytical purpose (Versnel 2011: 548-551). The Greek phrase that has caught most attention in the discussion is nomizein tous theous, carrying many meanings and can be translated "acknowledging the existence of the gods," "to worship the gods according to the cultic 
tradition," or just "to accept the gods in the normal way" (Parker 2011: 36 ; Versnel 2011: 552-558; Sedley 2013: 139-140). Harrison remarks (2015: 23) that the above suggested interpretations of nomizein tous theous are tightly related to the particular context in which it is used. In the Apology of Plato 26c, however, we have the first obvious example in which the verb nomizein clearly carries the meaning of "believing in the existence of gods," but the other meanings seem to be represented in that context as well.

"...these very gods about whom our speech now is speak still more clearly both to me and to these gentlemen; for I am unable to understand whether you say that I teach that there are some gods, and myself then believe that there are some gods and am not altogether godless and am not a wrongdoer in that way; that these, however, are not the gods whom the state believes in, but others, and this is what you accuse me for; that I believe in others or you say that I do not myself believe in gods at all and that I teach this unbelief to other people"(Plato's Apology 26c, translated by Harold North Fowler).

In what follows the quoted passage, the accuser of Socrates states that it is to believe that there are no gods that is on stake. Hence, the use of atheos in that passage means "atheist" in the modern sense rather than, at that time, common meaning of "godless" (Sedley 2013: 139).

Another important concept is the Greek asebeia. The meaning covers the significance of the English "impiety" but seems to have a broader range. Good relations to the gods, the family, and the society in general was crucial to most Greeks. When somebody in speech or act risked the harmony in those relations, such dangerous behaviour and/or speech was labelled asebeia (Bowden 2015: $325-336$ ). To sum up, the ancient Greeks used the term nomizein to refer to the propositions of the beliefs as well as for proper conduct in regard to divinities. Moreover, the term asebeia refers to unacceptable cultic conduct and asocial behaviour in general. We thus need to ask ourselves to what extent did the ancient Greek religion differ from a religion as for instance, Christianity, that often has been seen as dogmatically centred?

\section{Historical Developments}

If we exclude conversions, the leaving religion in antiquity is a non-existing field of research. However, I argue that there are reasons to alter this situation. Admittedly, however, there are many obstacles for the scholar who embarks on the journey of exploring the leaving religion in ancient times. To begin with, 
the sources are scant. Therefore, we will focus on Athens in the fifth century $\mathrm{BC}$, since that is a time with relatively abundant material to investigate. From that era, there are reports of persons who have later been considered as atheists. Nevertheless, there is not a single example of a person whom the majority of scholars have held to be an atheist. It is telling that the one who reads the chapter of atheism from the Pre-Socratics to the Hellenistic Age in The Oxford Handbook of Atheism (Sedley 2013) learns that atheism was a "recognizable if rare stance" (Sedley 2013: 150). Although many persons have been reported as atheists, there is no scholarly consensus according to which a certain person is held an atheist. This can be explained by how risky it would be to openly question the religious cult (Sedley 2013: 142, 144, and 147).

A resembling position is taken by Bremmer (2007) in The Cambridge Companion to Atheism. Atheism was never practiced, and theoretical atheism adhered to a small intellectual élite (Bremmer 2007: 11 and 19). According to Bremmer, the vast majority of people were embedded in an extremely religious society and never even thought of the possibility that gods may not exist (Bremmer 2007: 11). I side with Bremmer, Sedley, and the vast majority of scholars who stress that there is no evidence of practiced atheism in the sense of not taking part in religious cults. This is natural in a society in which the majority of people believed that cultic conduct was necessary for the society to sustain and thus would have seen as abstaining from taking part in the cult as a serious danger to all. But I claim that theoretical atheism means that one might mentally leave religion without practicing abstaining from taking part in the cult - this was far more common than hitherto has been thought. I also argue that somebody who was widely recognized as a theoretical atheist could nevertheless enjoy public high esteem.

\section{Major Controversies and Significant Case Studies}

Initially, we need to discuss to what degree beliefs in the ancient Greek religion can be accepted or rejected. Since enlightenment, the notion that people of old days did not critically question their own religion has been very influential. According to this master-narrative, the sceptical and scientifically-based reflection of religion generally only adhered to the modern human of the enlightenment and to those who followed that tradition (Stark 2015: 1-5). People who held that religions had ceased because of the scientific project that started with the enlightenment have used this discourse. This line of thought has been very strong and influenced the secularisation debate in the sociology of religion. Many of the founders of different theoretical perspectives in this field embraced an evolutionistic worldview according to which, religion would be 
replaced by science and ethics. Representatives of such a view were August Comte (1798-1857), Karl Marx (1818-1883), Émile Durkheim (1858-1917), and Max Weber (1864-1920) (McKenzie 2017: 3-10).

In the 1930's, the thoughts of classical sociologists of religions were supported by studies of how Europe was more and more de-Christianised. Here, Gabriel LeBras can be mentioned (McKenzie 2017:10). Thus, secularisation not only meant that religion had diminished in the public sphere of society but also described how religion in general gradually lost its significance in the private sphere. Proponents of this view from the 196o's were Brian Wilson, Peter Berger and Karel Dobbelaere (McKenzie 2017: 10; Stark 2015:4-5). Modern proponents of this view, such as Steve Bruce, have refined and defended this view, well aware of the different challenges this theory has faced (Bruce 2011).

From the 1980's, however, this position was questioned by scholars such as Rodney Stark, William Sims Bainbridge, and Roger Finke (Stark and Bainbridge 1985; Stark and Finke 1992, 2000). According to these scholars, the old churches of Western Europe have lost their importance. This observation, according to them, does not mean that religion is about to disappear but is rather undergoing transformation and revitalisation. Nowadays, however, many sociologists of religion take up intermediate positions and avoid predicting the future of religiosity. It would be impossible to summarise the views of different theorists in the scope of this chapter, but McKenzie 2017, especially $11-28$, provides an overview of the discussion.

I assert that the secularisation debate has influenced the view of ancient religions as well. According to the classical paradigm of sociology of religion, antiquity was characterised by a very high degree of uncritically accepted and foremost ritualistically orientated religiosities. I hold this as an important factor if we want to understand why theories on ancient Greek religion developed, according to which ritual played a predominant role, almost to the extinction of the study of ancient Greek myth in the history of ancient Greek religion (Bremmer 2014: 537-538). Ancient Greek myths were indeed studied but just at the fringes of history of ancient Greek religion. This state of affairs prevailed until the 1960's (Bremmer 2014: 538).

In the case of Robertson Smith (1846-1894), for example, the theoretical point of departure seemed very sound. He stressed that in order to understand ancient religions, one should do away with the concept of one's own-in his case, not forcing ancient religions into patterns of the Christianity of his time and place. Consequently, Robertson Smith, very much in line with the evolutionistic way of thinking at the end of the nineteenth century, contrasted ancient people to the preconceived more intellectually minded Christians of his day (Bell 1997: 161-162; Harrison 2015: 21). 
But seeing Classical Athens as a place with a low degree of intellectual debate regarding religion is of course untenable. For instance, in book ten of The Laws, Plato criticises views asserting they are widespread in Athens, probably in the latter half of the fifth or of the former half of the fourth century BCE. He mentions three views that the Athenian speaker in The Laws claims were widespread in his city. According to the first view, there is no god $(886 \mathrm{~d} 2-3)$; the second assertion is that gods are uninterested in what people do $(899 \mathrm{~d} 8-$ 9oob3); and, according to the third claim, gods can be bribed by sacrifices (905d4).

Of course, the pioneers of the study of religions, who to a degree far higher than the average scholar of today, were well versed in the Classical Greek literature and well acquainted with book ten of The Laws and other relevant examples. Both being aware of the lively debates in Classical Athens and, at the same time, asserting that ancient Greek religion was ritualistic and without intellectual dimensions must have caused problems. A way out of this intellectual dilemma of the nineteenth century scholars, and for surprisingly many contemporary scholars as well, has been, and to some extent still is, to identify themselves with the intellectual giants of Classical Athens and construct a huge gap between the intellectual élite and the masses who are often held responsible for not reflecting on religious matters. According to Lloyd-Jones (1971: 148), the imagined enlightenment of Classical Greece was a product of an unconscious identification of scholars of the last quarter of the nineteenth century. To the present day, such an identification has led scholars and artists astray when interpreting ancient Greek religion and drama (Lefkowitz 2016; Harrison 2015: 21-23). According to that line of thought, intellectual reflection on religion of ancient Greeks would be atypical and constitute a threat to the normative and supposedly ritualistically centred religion of Classical Greece. With this background in mind, it is easier to understand how leading scholars have both succeeded in bringing much new knowledge about rituals of the ancient Greek religion and, at the same time, misunderstood the importance of belief for the ancient Greeks. For a scholarly giant as Walter Burkert, for instance, Greek religion consisted in communally authorised practices. Although Burkert was a leading expert on mystery cults, these cults together with magic were seen as marginal phenomena, if at all included in the category of Ancient Greek religion (Burkert 1985).

In what follows, I side with a recent trend in the study of ancient Greek religion in which, the stereotype consisting of strictly regulated rituals contrasted to a virtually non-existent intellectual side is challenged. (Kindt 2012: 1-11; Osborne 2015; Kearns 2015; Harrison 2015; Eidinow et al. 2016). As Osborne (2015) and Kearns (2015) remark, both ritual practice and belief-system were 
far more flexible than usual. But how should we then conceptualise the ancient Greek religion?

The date of Euripides's drama Heracles is not certain. According to the stylistic analysis (Barlow 1996: 18), scholars often date it to the middle of his productive time, $420-415$ BCE. For a well commented translation of the text, I recommend Barlow (1996). The play opens as Heracles is away from home performing his labors. Meanwhile, Lycus, the tyrant of Thebes, persecutes Heracles's family. In the eleventh-hour Heracles returns. As his family tells him that Lycus had sentenced them to death, he kills Lycus. But in the moment of triumph, the tables turn. On behalf of Hera, goddesses Lyssa and Iris arrive, telling that they have come in order to drive Heracles mad so that he kills his own family (830-832). In a hallucinatory stage of madness, Heracles kills his family, believing that it is his enemy Eurystheus who he has defeated. Finally, Pallas Athene stops him and puts him in a deep sleep (1002). The only surviving member of his family who escaped is his earthly father, Amphitryon; after all, Zeus was Heracles's biological father. Amphitryon ties Heracles with ropes so that he and Heracles's friend Theseus can talk to the despairing hero and persuades him to not commit suicide (1351). At the end of the drama, Heracles decides to join Theseus on his journey to Athens.

How then would we interpret the drama? A lot seems to depend on the general view of the particular scholar on Classical Athens. As the literature on Euripides's drama Heracles is vast, I will delimit myself to follow the discussions of two leading scholars. Barlow (1996) represents a tradition of interpreting Euripides as a thinker who challenged the traditional religion of Archaic and Classical Greece. Lefkowitz (2016), however, opposes such interpretations and describes them as products of the modern scholar who has problems understanding ancient times. In her book, (1996) Barlow sees Classical Athens as an environment in which traditional and more authoritarian values adhering to earlier times are challenged.

"By classical times the art form was emancipated, and the authors free to change traditional treatments, criticise even the divine figures and sometimes, as Euripides did, show radical...scepticism about the gods, their morals and even their very existence. This is all the result of a...creative meeting between two worlds - the archaic, traditional, aristocratic, heroic world of... myth, and the newer contemporary values of the democratic, highly social city state where the...ordinary citizen's views counted in the general reckoning of 
human conduct and achievement, and where contemporary thinkers were questioning moral and theological issues" (Barlow 1996: xvi).

For her part, Lefkowitz describes the Greeks of Classical Athens as people who take it for granted that the gods do not care for or pity human beings. This is something that mankind simply has to accept; she sees no indication of people being opposed to such view (Lefkowitz 2016: 11-12). Let us now turn to their respective interpretation of the drama in question.

Barlow (1996: 8) notes that goddess Lyssa is reluctant to inflict madness on Heracles, as she sees him as pious and a benefactor to gods and the mankind (849-854). This, according to Barlow, is aimed at under striking Hera's destructive nature (1996: 8). It is in this light that Barlow reads Heracles's question as Hera triumphantly dances on Mount Olympus to celebrate her success in making Heracles slaughter his own family, "Who could pray to such a goddess? Out of jealousy for a woman loved by Zeus she destroyed the saviour of Greece who was guiltless" (1307-1308). Thus, according to Barlow, Heracles does not question the existence of gods but questions worshipping them (1341-1346).

It is not only Hera who is criticised in this drama. Zeus, the father of Heracles is described as a fake father who cannot take care of his own son (339-347; 1087-1088; 1127). Instead, Heracles recognizes Amphitryon's virtues by stating, "I consider you as my father, not Zeus" (1265).

But relations between persons are not at all unproblematic according to our drama. When Heracles comes home and understands that his family is in danger, he asks why his friends did not help his family. His wife Megara replies, "Who is friendly to a man in trouble?" (558-560). At the end, however, it is Heracles' friends Amphitryon and Theseus who rescue him and give him strength in life despite him killing his family. Finally, Heracles declares, "Whoever wants to acquire wealth or power rather than good friends is a fool!" (1425-14266).

Lefkowitz and Barlow agree that Heracles does not say that there are no gods. The drama rather describes a harsh reality where gods have power over mankind without moral obligations. But Lefkowitz does not agree with Barlow that our drama provokes the audience to think that the traditional worship is questionable: "There is no reason to suppose that anyone in the original audience would have been persuaded by Heracles" outburst to abandon traditional religious beliefs or practices" (Lefkowitz 2016: 54). Additionally, she stresses that there are many passages in Heracles in which the gods are praised: 735-739, 772-7780, and 811-814 (Lefkowitz 2016: 55). In that context, Lefkowitz argues that Euripides could have used those passages to prove that he was a pious person in the case of having been accused for impiety. I rather would say that such passages equally well could be explained by seeing Euripides as a clever theoretical atheist who did not want to be put on trial for impiety. 
I assert that the drama expresses a sharp critique of the public cult as well as of personal worship of gods. Although it is uncertain how many trials for impiety that actually took place in the fifth century BCE, I hold that there were reasons for a person as Euripides to be cautious. Bauman (1990) goes through the very problematic source-critical issues and argues that many trials actually took place. After all, Socrates was sentenced to death for impiety.

Key Figures

As I have tried to show in the previous part, Euripides is one of the most famous tragedians of world history and, at the same time, a person that we know very little about. He was probably born in the latter half of the 480's BCE and died at approximately 406 BCE. He seems to have spent most of his life in Athens where he was a renowned composer of tragedies. In some of Aristophanes' comedies, Euripides is closely associated with Socrates. Both Socrates and Euripides are described as crazy persons who by their lofty thoughts put the traditional Gods into question (Lefkowitz 2016: 26-28). It seems, however, that it is mostly Aristophanes' depiction of Socrates and Euripides that has coursed the views of later writers on Euripides (Lefkowitz 2016: 24-35). Of course, Aristophanes' Socrates and Euripides are persons intended for people to laugh at, and we should not build biographies on such basis. Nevertheless, Aristophanes' probable exaggerations sit well together with the view of Athens that Plato presents in the tenth book of The Laws. Athens was a city in which traditional religion was questioned, and the existence of gods sometimes was put in doubt.

However, opinions are divided regarding Euripides's own views on religion and even on how his dramas should be interpreted. Although there is no sign that he upheld a public office in Athens, he must have been held in high esteem due to his dramas and broad knowledge in many intellectual fields. He probably did not have a happy married life, but it is hard to say much about what it really looked like on the basis of the many slanders about it (Scodel 2017: 31). There are reasons to assume that he was famous both in Athens and worldwide (Scodel 2017: 27-29). Because of this, he was on one hand envied and on the other served as the ambassador for his city (Scodel 2017:33-35). My assumption is that Euripides was known as a theoretical atheist; this may have hindered him from taking on public positions in Athens but did not stop other states from accepting him as their ambassador (Scodel 2017:40) nor from being rewarded for his drama in Athens. 


\section{$7 \quad$ Conclusion}

The trend today is to stress that questioning religion and developing theology in ancient Greece is far more widespread as opposed to previously. Eidinow (2016) provides valuable discussions on how and why we actually can talk of theology in archaic and Classical Greece. The views of religion in Classical Athens, I would say, were much more diverse than what has been previously recognized and that makes room for the occurrence of atheism as well as deep personal devotion. I have not had the scope to discuss many thinkers other than Euripides who may have discarded the ancient Greek religion. I have referred to overviews as Whitmarsh (2015) who presses far in his endeavour to investigate whether there have been more atheists than assumed. It goes without saying that Euripides and persons such as Prodicus, to mention a few, were members of an intellectual élite (Mayhew 2011). However, in accordance with the new paradigm in the study of ancient Greek religion, I would say that questioning and reflecting on religions adhered to more than a few intellectuals in past times as well. In order to discard religion, however, one had to be willing to take risks. I hope that the present overview and discussion can open new perspectives and stimulate future research, not only of Classical Athens and Greece but also of the leaving religion in antiquity in general.

\section{References}

Barlow, S. 1996. Euripides's: Heracles. Warminster: Aris \& Phillips.

Bauman, R. 1990. Political Trials in Ancient Greece. New York: Routledge.

Bell, C. 1997. Ritual: Perspectives and Dimensions. New York: Oxford University Press.

Bowden, H. 2015. "Impiety." In E. Eidinow and J. Kindt, eds, The Oxford Handbook of Ancient Greek Religion. Oxford: Oxford University Press, 325-338.

Bremmer, J. 2007. "Atheism in Antiquity." In M. Martin, ed., The Cambridge Companion to Atheism. Cambridge: Cambridge University Press, 11-26.

Bremmer, J. 2014. "A Brief History of the Study of Ancient Greek Mythology." In K. Dowden and N. Livingstone, eds, A Companion to Greek Mythology. Chichester, West Sussex: Wiley Blackwell, 527-548.

Bruce, S. 2011. Secularization: In Defence of an Unfashionable Theory. New York: Oxford University Press.

Burkert, W. 1985. Greek Religion. Cambridge, Mass.: Harvard University Press.

Eidinow, E., Kindt, J., and Osborne, R. 2016. Theologies of Ancient Greek Religion. Cambridge: Cambridge University Press. 
Eidenow, E. 2016. Theologies of Ancient Greek Religion. Cambridge: Cambride University Press.

Harrison, T. 2000. Divinity and History: The Religion of Herodotus. Oxford: Oxford University Press.

Harrison, T. 2015. "Belief vs. Practice." In E. Eidinow and J. Kindt, eds, The Oxford Handbook of Ancient Greek Religion. Oxford: Oxford University Press, 21-28.

Kearns, E. 2015. "Old vs. New." In E. Eidinow and J. Kindt, eds, The Oxford Handbook of Ancient Greek Religion. Oxford: Oxford University Press, 29-38.

Kindt, J. 2012. Rethinking Greek Religion. Cambridge: Cambridge University Press.

Lefkowitz, M. 2016. Euripides and the Gods. Oxford: Oxford University Press.

Lloyd-Jones, H. 1971. The Justice of Zeus. Berkeley: University of California Press.

Mayhew, R. 2011. Prodicus. New York: Oxford University Press.

McKenzie, G. 2017. Interpreting Charles Taylor's Social Theory on Religion and Secularization: A Comparative Study. Cham: Springer International Publishing.

Needham, R. 1972. Belief, Language and Experience. Chicago: Chicago University Press.

Osborne, R. 2015. "Unity vs. Diversity." In E. Eidinow and J. Kindt, eds, The Oxford Handbook of Ancient Greek Religion. Oxford: Oxford University Press, 11-20.

Parker, R. 2011. Ithaca: Cornell University Press.

Scodel, R. 2017. "The Euripidean Biography." In L. McClure, ed, A Companion to Euripides. West Sussex: John Wiley \& Sons Inc.

Sedley, D. 2013. "From the Pre-Socratics to the Hellenistic Age." In S. Bullivant, and M. Ruse, eds, The Oxford Handbook of Atheism. Oxford: Oxford University Press, 139-151.

Sorensen, J. 2005. "Religion in Mind: A Review Article of the Cognitive Science of Religion." Numen. 52:4, 465-494.

Sperber, D. 1996. Explaining Culture: A Naturalistic Approach. Cambridge: Blackwell.

Sperber, D. 1997. "Intuitive and Reflective Beliefs." Mind and Language. 12:1, 67-83.

Stark, R. 2015. The Triumph of Faith: Why the World is More Religious Than Ever. Wilmington Delaware: ISI Books.

Stark, R., and Bainbridge, W.S. 1985. The Future of Religion: Secularization, Revival and Cult Formation. Berkeley: University of California Press.

Stark, R., and Finke, R. 1992. The Churching of America, 1776-1990: Winners and Losers in our Religious Economy. New Brunswick, N.J.: Rutgers University Press.

Stark, R., and Finke, R. 2000. Acts of Faith: Explaining the Human Side of Religion. Berkeley: University of California Press.

Versnel, H. 2011. Coping with the gods: Wayward readings in Greek Theology. Leiden: Brill.

Whitmarsh, T. 2015. Battling the Gods: Atheism in the Ancient World. New York: Alfred A. Knopf. 